\title{
58. Rus dilinde analitik ve sentetik gelecek zaman yapılarının görünüş ve kiplik anlamları
}

\section{Leyla Çiğdem DALKILIÇı}

APA: Dalkılıç, L. Ç. (2021). Rus dilinde analitik ve sentetik gelecek zaman yapılarının görünüş ve kiplik anlamları. RumeliDE Dil ve Edebiyat Araştırmaları Dergisi, (22), 905-917. DOI: $10.29000 /$ rumelide.897266.

\section{$\ddot{O} \mathbf{z}$}

Zaman kavramı neredeyse sınırsız ve sonsuz bir inceleme alanını yansıtmaktadır. Bu bakımdan da zaman kavramını ve anlamlarını net bir biçimde anlayabilmek için bu konu zaman eklerinin dışında bağlam, metinlerarası ilişkiler, kılınış, görünüş, kiplik gibi çok çeşitli kavramlar çerçevesinde incelenmelidir. Üç temel zaman dilimi çerçevesinde gelecek zaman yapıları geçmiş ve şimdiki zamana oranla dilde çok daha geç bir oluşumu yansıtmaktadırlar. Bu durum ise birçok dilde gelecek zamanın gerçekten var olup olmadığı tartışmalarını getirmekle beraber, farklı yaklaşımları doğurmuştur. Gelecek zamanın eylemin gelecekte yerine getirilecek olduğunun aktarıldı̆̆ı bir zaman dilimi olmanın ötesinde, çeşitli kiplik ifadelerini yansıttığı da gözlenmiştir. Rus dilinde hem oluşum süreçleri hem de dildeki diğer kategorilerin etkisi açısından gelecek zaman anlamı aktarıldığı yapılar ve anlamsal özellikleri bakımından çok çeşitlidir. Rusçadaki zaman yapıları görünüş kategorisi ile ilintili olarak ortaya çıktıklarından dolayı gelecek zaman yapılarının anlamsal özellikleri de bu kategorinin etkisi ile şekillenmektedir. Öte yandan görünüş anlamının dışında, konuşmacının herhangi bir olaya ilişkin tutumu, beklentisi, şüphesi, zorunluluğu, olasıllı̆ı gibi durumları da yansıtabildiği yani kiplik ifade edebildiği de gözlenmektedir. Bu çalışmada Rus dilindeki gelecek zaman yapıları aktardıkları anlamsal zenginlik çerçevesinde incelenecektir. Bu çalışmadaki amaç, gelecek zaman yapıları ile aktarılan eylemlerin yalnızca "gelecekte gerçekleştirilecek eylem” anlamını aktarmadığı, bunun ötesinde ret, inkâr, yeti, rica gibi çeşitli anlamları da aktarabildiğini ortaya koymaktır.

Anahtar kelimeler: Zaman kategorisi, gelecek zaman, gramer anlami, gramer formu, Rusça, görünüş

\section{Aspect and modality meanings of analytical and synthetic future forms in the Russian language}

\begin{abstract}
The concept of time reflects an almost limitless and endless field of study. In this respect, in order to understand the concept of time and its meanings clearly, it should be examined within the framework of various concepts such as context, intertextual relations, type of actions, aspect, modality. In the framework of three main tenses, the future tense structures in language reflect a much later formation compared to the past and present tense. While this situation brings the debate on whether the future tense really exists in many languages, it has led to different approaches. It was observed that the future tense, beyond being a time period in which the action will be fulfilled in the future, reflects various modal expressions. The meaning of the future tense in the Russian
\end{abstract}

Doç. Dr., Ankara Üniversitesi, Dil ve Tarih Coğrafya Fakültesi, Slav Dilleri ve Edebiyatları Bölümü, Rus Dili ve Edebiyatı ABD (Ankara, Türkiye), lcdalkilic@ankara.edu.tr, ORCID ID: 00oo-0o01-8801-6792 [Araştırma makalesi, Makale kayıt tarihi: 07.12.2020-kabul tarihi: 20.03.2021; DOI: 10.29000/rumelide.897266]

Adres | Address

RumeliDE Dil ve Edebiyat Araşttrmaları Dergisi $\quad$ RumeliDE Journal of Language and Literature Studies Osmanağa Mahallesi, Mürver Çiçeği Sokak, No:14/8 Osmanağa Mahallesi, Mürver Çiçeği Sokak, No:14/8

Kadıköy - İSTANBUL / TÜRKIYE 34714 Kadıköy - ISTANBUL / TURKEY 34714 e-posta: editor@rumelide.com

e-mail: editor@rumelide.com

tel: +90 505 7958124, +90 216773 o 616 phone: +90 505 7958124, +90 2167730616 


\begin{abstract}
language is very diverse in terms of structures and semantic features, which it conveys both from the point of view of the formation processes and the influence of other categories in the language. Since the tense structures in Russian appear in relation to the aspect category, the semantic properties of future tense structures are also shaped by the effect of this category. On the other hand, apart from the meaning of aspect, it is observed, that the speaker can also reflect the situations such as attitude, expectation, suspicion, necessity, possibility of an event and it can be noted that modality is possible to express by means of these forms. In this study, the future tense structures in the Russian language will be examined within the framework of the semantic richness they convey. The aim of this study is to show, that actions conveyed by means of future tense structures do not only convey the meaning of "action to be carried out in the future", but also convey the various meanings, such as rejection, denial, capacity, request.
\end{abstract}

Keywords: Tense category, future forms, grammatical meaning, grammar form, Russian, aspect

\title{
Giriş
}

Gelecek zaman cümlede konuşma anından sonraki bir duruma ya da konuşma anı ile düşünsel olarak denk bir konuma sokulan başka bir duruma işaret eden fiilin çekimli formudur. Gramer kategorilerinin ifadesinde sadece bir araç rolü oynayan ve kelimenin temel anlamına etki etmeyen kelime formları, dildeki diğer çeşitli gramer kategorilerinin ifadesinde olduğu gibi gelecek zaman yapılarının aktarımında belirgin bir role sahiptir. Konuşma anından sonrasına işaret etme temel anlamının dışında bu yapı Latince, Almanca, Romence, Türki diller gibi kimi dillerde çeşitli formlarda var olabilmektedir (Maslov, 2004: 516). Örneğin, Latin dilinde gelecek zamandaki olayı belirten basit gelecek zamanın (futurum simplex) yanı sıra gelecek zamanda tamamlanması beklenen olayların aktarıldığı ön görülen gelecek zaman (futurum exactum) ve geçmiş zamanda gerçekleşecek olması ön görülmüş olan olayların belirtildiği geçmiş zamanda gelecek (futurum praeteriti) yapıları bulunmaktadır. Yine Türk dilinde henüz gerçekleşmemiş bulunan ancak fiilin gösterdiği oluş ve kılışın gelecekteki zaman diliminde mutlaka gerçekleşeceğini bildiren temel anlamlı gelecek zaman yapısının yanı sıra, ön görülen gelecek zaman ve anlam kaymaları çerçevesinde gelecek zamanın görülen ve duyulan geçmiş zaman anlamlarında kullanılan yapıları mevcuttur (Korkmaz, 2009: 631-636). Slav dillerinde ise zaman kategorisi görünüş kategorisinin etkisi altında anlam kazanmaktadır. Bu bakımdan gelecek zaman yapıları bitmemişlik türünde (будy решать - çözeceğim) ve bitmişlik türündeki (peuy - çözeceğim) fiil gruplarından iki farklı yapıda olan ve anlamsal çeşitliliğe sahip fiil çifti şeklinde dilde görülmektedir. Temel gelecek zaman anlamının dışında ön görülen gelecek zaman anlamı tekrar eden genel geçer kabul edilen eylemlerin ifadesinde yer alır. Almanca, İngilizce gibi bazı dillerde ise gelecek zaman anlamları olasılık ve varsayımda bulunma anlamları başta olmak üzere istek, niyet gibi duygusallık faktörü olan kiplik anlamları ile ilişkilendirilmiştir (Selişev, 1952: 175).

$\mathrm{Bu}$ çalışmada gelecek zaman daha spesifik bir çerçeveden, Rus dili temel alınarak incelenecektir. Rusçada iki farklı yapıdaki fiil çifti ile aktarılan bu formların anlamları, kullanım özellikleri ve aynı temel anlamı yansıtsalar bile neden birbirinin yerine kullanılamayacakları, ne açılardan birbirinden ayrıldıkları incelenmektedir. Yabancı bir dil olarak Rusçanın öğretilmesi sürecinde bu yapıların kullanımında öğrenciler tarafından sık yapılan hatalar, dilin gramer ve görünüş kategorisinin özünün tam olarak anlaşılamamasından kaynaklanmaktadır. Bu çalışmada amaç Rus dilindeki gelecek zaman yapılarının anlamsal ve işlevsel özelliklerini geniş bir çerçeveden ele alıp incelemek, böylece ilgili kitlelere sunup dildeki zaman-görünüş kategorisine ilişkin farkındalık kazandırmaktadır. Gelecek zaman yapılarının anlamsal ve işlevsel özellikleri Rusça örneklerin Türkçe açıklamalı çevirileri ile

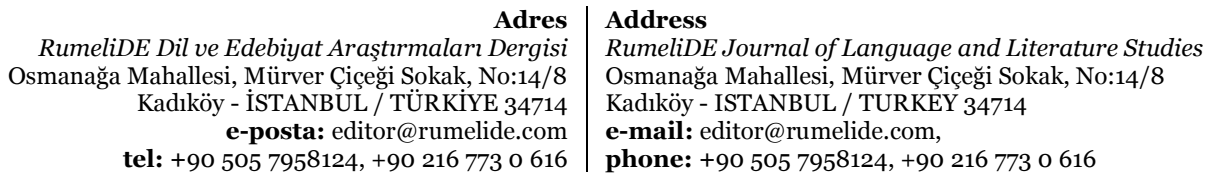


aktarılacaktır. Böylece sunulan materyalin bilişsel açıdan daha iyi bir biçimde özümsenmesi de ayrıca hedeflenmektedir.

\section{Gelecek zaman yapıları}

Bir gramer kategorisi olarak gelecek zaman şimdiki ve geçmiş zamana oranla geç bir oluşumu yansıtmaktadır. Bu teori gelecek zaman formlarının yerine geleceğe yönelik eylemlerin şimdiki zaman formları ile aktarılmaları veya bir dilde gelecek zamana ilişkin formların ve anlam açısından kesin sınırların bulunmadığı paralel yapıların bulunması ile de desteklenmektedir. Bu açıdan gelecek zaman yapılarının her dilde mevcut olmadığı ya da sadece kiplik anlamlarını aktarmak için bir araç olarak kullanıldığına yönelik görüşler mevcuttur. Bu yaklaşım bilhassa İngiliz dili gramercileri tarafından desteklenmektedir (Bradley, 1911: 5-6; Fries, 1925: 965, İzraileviç ve Kaçalova, 2003:115-117, 207-216).

Gelecek zaman anlam açısından kiplik ve görünüş anlamlarını yansıtmaları bakımından iki şekilde ele alınmaktadır. Gelecek zamanın kiplik anlamı istek, zorunluluk veya olasılık anlamlarının yeniden şekil bulup anlam kazanması ile ortaya çıkmıştır. İngilizcede başlangıçta anlamı "istek" olan will ile "zorunluluk" belirten shall yardımcı fiilleri buna örnektir. Slav dillerinde de gelecek zamanın kiplik anlamları için benzer bir gelişim söz konusudur. Güney Slav dillerinden Sırpça ve Hırvatçada nucaちy, Bulgarcada ще пиша (буду писать - yаzacağım) ifadesi gelecek zaman "istiyorum" anlamındaki fiilden türemiştir, yine aynı şekilde Eski Slavcada (должен - zorunlu, gerekli) anlamındaki imamь (имею) fiili Ukraynacada bitmemişlik türlü gelecek zaman için kullanılmaktadır (Maslov, 2003: 517). Rusça için gelecekte yapılması ön görülen eyleme ilişkin bir niyet, dilek gibi kiplik anlamlarının belirtilmesi ise "быть" yardımcı fiili ile aktarılmaktadır. Rus dilindeki bitmemişlik türün birinci tekil şahıs gelecek zaman fiil çekimi olan бydy fiilinin anlamı, başlangıçta "büyümek, yetişmek - pacmu" anlamına gelen "olmak, meydana gelmek, gerçekleşmek" anlamlarına sahip Hint-Avrupa kökenli -bhu fiilinden türemiştir (Maslov, 2003: 517).

Gelecek zamanın görünüş anlamları ise bitmişlik anlamına sahip fiil türleri ile ilişkilendirilmekte ya da başlangıç anlamına sahip fiil yapılarından türedikleri düşünülmektedir. Örneğin, Almanca için "halini almak, olmak" anlamına gelen werden fiili ya da Rusça yine aynı şekilde "halini almak, olmak, başlamak" anlamlarında kullanılan "стать - станy" fiilinden oluştuğu düşünülmektedir (Maslov, 2003: 518).

Rus dilinde gelecek zaman formları için her iki fiil çiftinde de görünüş ve kiplik anlamları görülmekte olup her bir fiil çifti hem kendine has temel anlamlara ve yan veya alt anlamlara sahiptir. Bu bakımdan da her bir yapı işlevsel olarak birbirinden ayrılmaktadır (Çuykova, 2019: 234). Bundan sonraki bölümde bitmemişlik türüne ait fiillerle oluşturulan analitik gelecek zaman yapıları ile bitmişlik türüne ait fiillerle oluşturulan sentetik gelecek zaman yapılarının anlamsal ve işlevsel özellikleri ayrıntılı olarak ele alınacaktır.

\section{Analitik gelecek zaman yapıları}

Yukarıda da belirtildiği üzere gelecek zaman yapıları şimdiki ve geçmiş zamana oranla geç bir oluşumu yansıtmaktadır. Eski Rusçada gelecek zamanın ifadesi ayrı bir anlam yapısı ile aktarılmamakta, geleceğe yönelik her türlü söylem belirli kiplik anlamlarını barındıran ifadelerle yansıtılmaktaydı. Çeşitli kiplik anlamına sahip fiiller istek (хочю на вы ити), veya niyet belirtmekteydi, bazen de

иду на вы -savaş ilan etmek, düşmana karşs ilerlemek.

Adres $\mid$ Address

RumeliDE Dil ve Edebiyat Araștrmaları Dergisi $\quad$ RumeliDE Journal of Language and Literature Studies

Osmanağa Mahallesi, Mürver Çiçeği Sokak, No:14/8 Osmanağa Mahallesi, Mürver Çiçeği Sokak, No:14/8

Kadıköy - İSTANBUL / TÜRKIYE 34714 Kadıköy - ISTANBUL / TURKEY 34714 e-posta: editor@rumelide.com

e-mail: editor@rumelide.com

tel: +90 $5057958124,+90216773$ o 616 phone: +90 505 7958124, +90 216773 o 616 
gelecek anlamı faz3 belirten иму, стану, дълати gibi fiillerin yardımıуla aktarılmaktaydı (Kolesov, 2010: 279). Будy yardımcı filli ile gelecek zamanın ifadesi dilde geç dönem bir oluşumu yansıtmaktadır. Bu yapı ile Rusçada gelecek zaman aktarımının yaygınlaşmasının XVII. yüzyılda Lehçenin dil üzerine aktif etkisi ile ilintili olduğu düşünülmektedir. Rus dilbilimci V.V. Kolesov, benzeri yapıların genel olarak Eski Rus dili halk lehçeleri4 ve Güneybatı ağızlarından olmak üzere XIV. yüzyılın ortalarından itibaren dile geçtiklerini, XIII. yüzyılın başlarında ise Smolensk yazıtlarında bu yapıların kullanımına ilişkin birkaç örneğe rastlanıldığını, benzer şekilde Velikorus kaynaklarında gelecek zamanın bu yapılarına ilişkin örneklerin XV. yüzyılın ortalarından itibaren belirgin olarak görülmeye başlandığını ve kullanımlarının artarak devamlı hale geldiklerini ifade etmektedir (Kolesov, 2010, 279).

Buradan hareketle çağdaş Rus dilinde bu yapı ile aktarılan gelecek zaman anlamları dilde analitik gelecek zaman olarak zaman ulamı içerisinde yer bulmuştur. Bitmemişlik türü fiil grubuna ait eylemlerin mastar hallerinin günümüzde "olmak" anlamına sahip быть yardımcı fiilinin şahıslara göre çekimlenerek kullanılması ile oluşturulmaktadır: буду решать, буду писать, буду читать vb. İki gramer yapısı ile oluşturulduklarından analitik yapılı gelecek zaman formları (аналитические формы будущего времени) уа da birleşik gelecek zaman yapıları (сложные формы будущего времени) şeklinde dilde ifade edilirler.

Rus dilinin gelecek zamana ait gramer anlamları ifade aracına bağlı olarak bir gramer yapısı (peшy) veya iki gramer yapısı (буду решать) ile aktarılmaktadır. Tek gramer yapısı ile aktarılanlar sentetik gelecek zaman formları, iki gramer yapısına sahip olanlar ise analitik gelecek zaman formları olarak adlandırılmaktadır. Rus dilinde her bir gramer kategorisinin, her bir yapının bir temel bir de yan olmak üzere yardımcı anlamları vardır. Analitik gelecek zaman yapıları için de durum aynıdır. Bu yapıların temel anlamı ifade edilen eylemin konuşma anından sonrasını yansıtmasıdır. Söz gelimi, $A$ буду читать (Bеп окиуасайıт), Он будет смотреть (o izleyecek) gibi bağlam dışında kullanılan sade ifadeler geleceğe yönelik eylemleri işaret ederken, birkaç anlamı da yansıtmaktadırlar:

1) Görünüş kategorisi ile ilintili olarak eylemin sadece gelecekte vuku bulacağına yani yerine getirilmiş olacağına, gelecek zaman dilimi içerisinde yer edebileceğine vurgu yapılmaktadır. Bu özelliği bitmemişlik görünüşünün genel-gerçeklik (общефатическое значение) 5 anlamı ile ilintilidir. $\mathrm{Bu}$ yapıları belirli bir olay çerçevesinde yani durum odaklı olarak inceleyecek olursak söylenmek istenen daha net bir şekilde anlaşılacaktır: 1) - Что у нас будет завтра на занятии? - Мы будем писать сочинение $^{6}$ (Yarın derste ne yapacağız? - Kompozisyon yazacağız ); 2) В этом году мой старший брат будет поступать в университет на юридический факультет (Abim bu sene üniversiteye, hukuk fakültesine girecek7); 3) В июне мой друг будет защцщать диссертацию (Arkadaşım temmuz ayında savunmaya girecek). Örneklerden görüleceği üzere her üç ifadede gelecekte gerçekleşmesi muhtemel, olacak olması öngörülen, bir derece planlanan ve böylece de gelecek zaman diliminde yer edecek olan eylemler söz konusudur, burada eylemin gerçekten gerçekleşip gerçekleşmeyeceğinin konuşan için bir önemi olmadı̆̆ı gibi muhakkak suretle gerçekleşeceklerine de

3 Фазисные глаголы- başlangıç-süreç-bitiş gibi belirli safha veya evre anlamlarına sahip fiillerdir. Rusçada bu fiillere örnek olarak начинать, продолжать, заканчивать gibi fiiller ve bu fiillerin çiftleri örnek gösterilebilir.

Burada Eski Belarusça ve Eski Ukraynaca diyalektleri kastedilmektedir.

M.A. Şelyakin bu anlamı обобщенно-фактическое действия adı altında incelenmekte ve görünüş anlamının dışında tutulmaktadır. Bkz.: M.A. Şelyakin’in “Kategoriya aspektualnosti russkogo glagola”. M., s. 192.

Burada ve bundan sonra verilen kısa cümle örnekleri G.L. Skvortsova'nın "Upotreblenie vidov glagola v russkom yazıke. Russkiy glagol" adlı çalışmasından derlenmiştir. s.59-61.

$\mathrm{Bu}$ örneğin verdiği anlamı inceleyecek olursak aslında kullanılan gelecek zaman formları ile eylemin gelecekte kesin olarak gerçekleşeceği değil yapılacağı ifade edilmektedir. Diğer bir deyişle, kişinin üniversite eğitimi için sınava gireceği ve bu bakımdan üniversiteye girme niyeti anlatılmaktadır.

Adres $\mid$ Address

RumeliDE Dil ve Edebiyat Araşttrmaları Dergisi $\quad$ RumeliDE Journal of Language and Literature Studies Osmanağa Mahallesi, Mürver Çiçeği Sokak, No:14/8 Osmanağa Mahallesi, Mürver Çiçeği Sokak, No:14/8

Kadıköy - İSTANBUL / TÜRKIYE 34714 Kadıköy - ISTANBUL / TURKEY 34714 e-posta: editor@rumelide.com tel: +90 505 7958124, +90 2167730616 phone: +90 505 7958124, +90 2167730616 
herhangi bir vurgu yapılmamakta sadece eylemin gelecekte vuku bulacağı ya da yer edeceği/etmiş olacağı aktarılmaktadır.

2) Zaman belirten ifadeler ile kullanıldığında gelecek zamana yönelik eylemin sürecine, süreçsel uzunluğuna vurgu yapılmaktadır. Burada bitmemişlik türlü fiillerin sürerlilik (процессность) anlamı ön plana çlkmaktadır: 1) Студенты будym nuсать экзаменационную работу четыре часа (Öğrenciler 4 saat kontrol sinavı olacaklar); 2) На подготовительном факультете студенты будут изучать русский язык 10 месяцев (Hazırlık sınıfında öğrenciler 10 ay Rusça öğrenecekler); 3) Курсы английского языка будут длитъся всего три месяца (İngilizce kursu sadece üç ay sürecek). Bu anlamın ortaya çıkması için mastar halde kullanılan fiillerin eylemin süreç ve uzunluk özelliklerine sahip olmaları gerekmektedir8.

3) Gelecekte tekrar etmesi ön görülen ya da tekrar edecek olan eylemler de zaman zarfı yardımıyla, tekrar eyleminin süresi belirli kılınarak aktarılır. $\mathrm{Bu}$ anlamda bitmemişlik türün tekrar (повторяемость) ve düzen (регулярность) anlamları belirtilmektedir. 1) Я буду часто писать письма родителям о моей жизни в Мосвке (Moskova'daki yaşamım hakkında aileme sık slk mektup yazacağım); 2) Марта купила абонемент в консерваторию, теперь по воскресеньям она будет слушать симфоническую музыку (Marta konservatuar aboneliği ald, artık Pazar günleri senfoni orkestrasını dinleyecek); 3) Теперь я буду заниматься спортом каждый день (Artık her gün spor yapacağım).

4) Gelecek zaman analitik yapıları iletişim anında konuşanın dinleyene yönelik olarak gelecek zaman diliminde aktardığı ifadelerin, dinleyicinin konuşma anından sonraki eyleme geçmesi için kullanılır. Benzeri kullanımlarda konuşan dinleyiciyi kişi/kişileri harekete geçirme eylemini gerçekleştirmektedir. 1) - Закройте книги. Откройте тетради. Сейчас вы будете пuсать контрольную

работу (-Kitapları kapatın, defterleri açın, şimdi kontrol sınavı olacaksınız); 2) Выключите свет пожалуйста! Сейчас мы будем смотреть фильм (Işıkları kapatalım lütfen, şimdi filmimizi izleyelim); 3) Накрой на стол. Сейчас будем обедатъ (Masayı kur, şimdi yemek yiyeceğiz). Benzeri cümlelerde genel olarak komut ve gelecekte yapılacak eylemleri sıralama anlamları da ortaya çıkmaktadır ancak bunlar ikincil anlamlar olarak algılanmalıdır.

Kısa cümle yapılarında analitik gelecek zaman yapılarının anlamsal özellikleri dört temel çerçevede ele alınabilir, bunun yanı sıra bu formların kullanımındaki sıkıntılar çoğunlukla yan cümle kullanımlarında yaşanabilmektedir. Benzeri durumlar daha çok zarf-fiil yapılı ve zaman bağlaçlı cümlelerde görülmektedir: 1) Для того, чтобы добраться до места назначения, мы погрязая в глине будем продвигаться (прөдешнемея) вперёд (Varış yerine ulaşabilmek için çamura bata çlka ilerleyeceğiz); 2) Увидев 9 меня, он убежит; (Beni görünce/görüp kaçacak)10 3) Говорил: когда подрастем, займем руководящие посты и будем проводить (прөөедём) ${ }^{11}$ свою политику (Büyüyeceğimiz ve yönetici pozisyonları ele geçirdiğimizde kendi politikamızı yürüteceğiz). [Александр Терехов. Каменный мост (1997-2008)]; 4) Хотя, когда потеплеет, конечно,

Orneklerde sunulan fiillerin yanı sira чumamb, ждаm
anlamına sahip eylemlere örnek olarak gösterebiliriz.

9 Rusçada zarf-fiil yapılarıyla zaman anlamlarının kullanımı için bkz. L.Ç. Dalkılıç Rusça ve Türkçedeki Zarf-Fiil Yapılarındaki Anlamsal Özellikler ve Zaman Kavramı. DTCF. 2018, s. 1184-1210.

Önek tarafimiza aittir.

11 Bu örnekte parantez içerisindeki seçenek mümkün olabilmekle birlikte gelecekte düzenli eylemlere işaret etmediği için mantıken dil kullanımına ters düştüğünden tercih edilmemelidir.

Adres $\mid$ Address

RumeliDE Dil ve Edebiyat Araştırmaları Dergisi $\quad$ RumeliDE Journal of Language and Literature Studies Osmanağa Mahallesi, Mürver Çiçeği Sokak, No:14/8 Osmanağa Mahallesi, Mürver Çiçeği Sokak, No:14/8

Kadıköy - ISTANBUL / TÜRKIYE 34714 Kadıköy - ISTANBUL / TURKEY 34714 e-posta: editor@rumelide.com

e-mail: editor@rumelide.com,

tel: +90 505 7958124, +90 2167730616 phone: +90 505 7958124, +90 2167730616 
будем спать (пөеплө) с открытой форточкой (Havalar ısındığında, elbette ki, pencereyi açıр uyuyacağız). [Наши дети: Малыши до года (форум) (2004)] ${ }^{12}$.

Bu ve benzeri kullanımların mümkün olamamasının sebebi eylemin sürerlilik (продолжительность) ve sürersizlik (непродолжительность) ${ }^{13}$ anlamlarının yanı sıra aslında fiil türlerinin sahip olduğu sinırlılık/sinırsızlık (предельность/непредельность) ilkesinde yatmaktadır (Koşevaya, 2016: 178). Sınırlılık veya kimi çalışmalarda ${ }^{14}$ ele alındığı şekliyle (лимитативность) "kısıthlık", eylemin ortaya çıkışını sınır kavramı açısından farklı anlamsal sınıflandırmalar çerçevesinde inceleyen semantik bir kategoridir. Eylemin sınırı genel anlamı itibariyle eylemin meydana gelişindeki kısıtlılığı ortaya koyan zamansal bir sınırı ifade etmektedir. Eylemin sınır anlamı ile olan ilişkisi çok çeşitli olabilmektedir. İç ve dış sınır, gerçek ve olası sınır, açık ve kapalı, mutlak ve göreceli sınır olmak üzere anlamlara ayrılmaktadır. İç ve dış sınıra bakacak olursak, dış sınırda zamansal olarak eylemin meydana gelişinin eylemin kendisine değil de dış etmenlere bağlı olarak ortaya çıktığı durumlardır: Он ждал тебя до пяти часов (Seni saat beşe kadar bekledi); Буду отдыхать пока меня не беспокоят (Вепі rahatsız etmedikleri sürece dinleniyor olacağım) ${ }^{15}$ ve benzeri söylemlerde "bekleme" ve "dinlenme" eylemlerinin sınırı yani zamansal açıdan vuku bularak bir sınır belirtmesi zarflar yardımıyla ortaya konmaktadır. Dııs sınırda ise eylemin zaman içerisindeki akışı eylemin kendisi ile belirlenmektedir, herhangi bir dış faktöre ihtiyaç yoktur, kullanılsa bile sınırlılık anlamı belirgin olarak korunur:

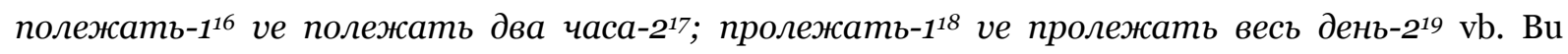
açıdan sınırlılık, fiilin sahip olduğu iç anlam çerçevesinde, söz konusu eylemin belirli bir zaman çizgisi içerisinde meydana gelişinin tam manasıyla ve tüm anlamıyla son noktasına kadar tezahür etmesidir. İç sınırda fiilin kendi iç anlamında bu kavram bulunurken, dış sınırda bu anlamın yakalanabilmesi için eylemin zamansal akışını belirgin kılan yardımcı araçlara ihtiyaç vardır. Bu durumu başka bir örnek ile açlklayacak olursak, no-cuдеть ([biraz] oturmak), nро-сидеть ([uzunca bir süre] oturmak) fiilleri dilde hem sahip oldukları ön eklerin anlamları hem de ait oldukları bitmişlik görünüş türünün özelliklerinden dolayı eylemin ortaya çıkışını tüm boyutuyla yani başlangıç ve bitişi ile bir bütün olarak kapsamakta ve eylemin bu açılardan uygulanıp sona erdiği tüm potansiyeli ile vuku bulduğu anlamları mevcuttur. Bu ve benzeri fiillerde hareketin ya da eylemin kendisine değil, tüm manasiyla nasıl ortaya çıkıp meydana geldiği vurgulanmaktadır. Krş.:

Он просидел дома цельй день = Bütün gün evde oturdu

Он сидел дома цельй день = Bütün gün evde oturdu

Her iki ifadenin de Türkçeye aynı aktarıldığı bu cümlelerdeki fark iç anlamlında yatmaktadır. Birinci fiil ile eylemin belirtilen zaman sınırı içerisinde tüm gerçekliği ile yansıdı̆̆ı, eylemin tüm gün zaman sınırı içerisinde tezahür ederek gerçekleştiği, tamamlandığı vurgulanırken, ikinci fiil ile belirtilen

Örnekler национальный корпус русского языка adlı Rusçanın Ulusal Derlemi sitesinden seçilmiştir.

Sürerlilik/sürersizlik ifadeleri eylemin sürekli yapılmakla birlikte devaml olduğunu aktarmak adına tarafımızca kullanımı tercih edilmiş bir kelimedir. Rus dilinde постоянность terimi için süreklilik anlamsal açıdan daha yakın bir konumda bulunduğundan ötürü ise bu kavramı aktarmak için tercih edilmemiştir. Tarafımızca kullanılan ifade yalnızca bir öneri mahiyetine sahiptir.

Bkz. Teoriya funktsional'noy grammatiki, M.: Komkinga, 2007. s. 46.

Metne göre farklı aktarımlarla dile yansitılabilecek olan bu ifadede söylenmek istenen kişinin onu herhangi birisi arayıp sormayana, bir şekilde rahatsız etmeyene kadar, dinlenme eylemini sürdürerek gerçekleştirilecek olmasıdır.

По - kısa bir süreliğine - лежать - yatmak, uzanmak.

"Kısa bir süreliğine yatmak, uzanmak" eylemini iki saatlik zaman sınırı çerçevesinde, "kendince kısıtlı olan bir zaman dilimi içerisinde" tamamlamak.

Про- eyleme eklendiğinde çoğunlukla "uzun” olmak üzere bir sürede devam ederek eylemin gerçekleşmesi anlamını verir, лежать - yatmak, uzanmak.

"Uzunca bir süre yatmak, uzanmak" eylemini tüm gün olmak üzere zaman sınırı çerçevesinde, "kendince uzun olan bir zaman dilimi içerisinde” tamamlamak.

Adres RumeliDE Dil ve Edebiyat Araştırmaları Dergisi Osmanağa Mahallesi, Mürver Ciçeği Sokak, No:14/8 Kadıköy - ÍSTANBUL / TÜRKIYE 34714 e-posta: editor@rumelide.com tel: +90 505 7958124, +90 2167730616
Address

RumeliDE Journal of Language and Literature Studies

Osmanağa Mahallesi, Mürver Çiçeği Sokak, No:14/8

Kadıköy - ISTANBUL / TURKEY 34714

e-mail: editor@rumelide.com,

phone: +90 505 7958124, +90 2167730616 
eylemde sadece geçmişte yapılmış olan bir oturma aktivitesinin olduğuna vurgu yapılmaktadır. Birincisinde uzunca olmasına rağmen bir zaman sınırlı içerisinde tamamlanış bir eylem söz konusu iken, ikincisinde var olmuş olan yapılmış olan bir eylem söz konusudur.

Rus dilinde gelecek zaman yapıları gramer açısından her zaman sınırlılıkº özelliğine sahiptirler, ancak aynı gramer anlamını aktaran yapılar ulaşılmış ve ulaşılmamış olan yani sınır noktasına ulaşmışlıkları /tamamlamışlıkları (достигнутость) ve sınır noktasına ulaşmamışlık/ tamamlanmamışlıkları ${ }^{21}$ (недостигнутость) açısından ikiye ayrılmaktadır. Eylemlerin sınır noktasına ulaşmışlıkları/tamamlanmışlıkları ve sınır noktasına ulaşmamışlıklarına/tamamlanmamışlıklarına ilişkin aşağıdaki örnek bu yaklaşımı belirgin olarak ortaya koyabilir:

Он уговаривал папу, но не уговорил = Babasını ikna etmeye çalsştı ancak ikna edemedi.

Birinci fiil çekimi ile eylem sınır noktasına ulaşamamıştır, ikinci fiil çekimi ile eylemin sınır noktasına ulaştığı aktarılmıştır. Buna göre bitmişlik görünüşlü fiiller tamamlanmış bir sınırlılık yani sınır noktasına ulaşılmış bir tamamlanmışlı özelliği ortaya koyarlar, bu özellik esasen fiil türünün doğasında vardır. Bitmemişlik görünüşlü fiil türü ise, tam tersi olmak üzere, tamamlanmamış bir sınıllılık yani sınır noktasına ulaşılmamış bir durum sergiler. Analitik gelecek zaman yapılarının tek başına kullanımlarında bu durum bilhassa belirgindir: буду делать (уарасайıт), буду читать (okuyacağım) gibi ifadelerde eylemin kendisi bir sınır belirtirken, bu sınır noktasına ulaşılması ya da ulaşlacak olmasına ilişkin herhangi bir gösterge veyahut anlamsal nüans bulunmamaktadır. Tamamlanmamışlık anlamına sahip bu ve benzeri formlar eylemsel olarak belirli bir sınıra işaret etse de mastar halinde kullanılan bitmemişlik türü fiil nedeniyle eylemin tamamlanırken sınır noktasına ulaştığına ilişkin bilgi eksik kalmaktadır. Bu da analitik gelecek zaman yapılarını sentetik gelecek zaman yapılarından ayıran en önemli noktadır.

Konuya ilişkin olarak dilbilimci İ.G. Koşevaya analitik gelecek zaman yapılarındaki бydy ifadesinin, sentetik gelecek zaman formlarında görüldüğü gibi (по-строить), yapılara sınırlılı anlamını katan bir ön ek görevi gördüğünü ancak kendisinden sonra gelen bitmemişlik görünüşlü fiil türü nedeniyle ulaşllmışlık (достигнутость) anlamından yoksun olduğunu vurgulamaktadır (Koşevaya 2016: 179). Bununla birlikte analitik gelecek zaman yapıları ile sentetik gelecek zaman yapılarının sınır noktasına ulaşmışlıkları/tamamlamışlıkları ve sınır noktasına ulaşmamışlıkları/tamamlanmamışlıkları açısından ele alınabileceklerini savunmaktadır (Koşevaya, a.g.e: 180). Bizce bu yaklaşım, izole kullanımların dışında analitik gelecek zaman yapılarının bilhassa yukarıdaki yan cümle örneklerinde de görüldüğü üzere neden her zaman kullanılamayacaklarını açılamaktadır.

Analitik gelecek zaman yapılarının görünüş anlamlarının yanında bizce kiplik anlamına yakın olan ve kullanıldığı duruma göre eylemin yapılacak olmasından ziyade daha çok geleceğe yönelik bir niyete, isteğe işaret eden veya bir duygu gösterebilen durumlarda da kullanılabilmektedir. Söz gelimi aşağıda verilen örnek cümlelerde²2 bunu açlkça görebiliriz:

1) «Они захотят узнать о вас как можно больше. Я буду писать мемуары о вас. Я должен буду писать чистую правду. И что прикажете делать с некоторыми фактами?» [Алексей Слаповский. Гибель гитариста (1994-1995)] Krş.: .... Я хочу пuсатъ мемуары о вас....

Rus dilbiliminde sınırlılık konusuna ilişkin ayrıntılı bilgi için bkz. Teoriya funktsionalnoy grammatiki. M., s.45-66. Rusça terimlerin Türkçe karşıllıları tarafımıza aittir. Örnekler национальный корпус русского языка adlı ulusal derlemden seçilmiștir.

Adres | Address

RumeliDE Dil ve Edebiyat Araştırmaları Dergisi $\quad$ RumeliDE Journal of Language and Literature Studies Osmanağa Mahallesi, Mürver Çiçeği Sokak, No:14/8 Osmanağa Mahallesi, Mürver Çiçeği Sokak, No:14/8 Kadıköy - ISTANBUL / TÜRKIYE 34714 Kadıköy - ISTANBUL / TURKEY 34714 e-posta: editor@rumelide.com e-mail: editor@rumelide.com, tel: +90 505 7958124, +90 2167730616 phone: +90 505 7958124, +90 2167730616 
Çev.: "Sizin hakkınızda mümkün olduğunca çok şey öğrenmek isteyeceklerdir. Sizin hakkınızda bir anı yazacă̆ım, tüm Gerçeği yazmak gerekecek. Peki bazı gerçeklerle ne yapmamı istersiniz?”

2) «Буду новую книжку писать - обязательно напишу про эту деревню". - И про нас напиши! - послышался вдруг близкий и хриплый голос. Я вздрогнул». [Юрий Коваль. Про них (1988)] Krş.: .... Я хочу новую книжку писать....

Çev.: "Yeni bir kitap yazacă̆ım - mutlaka bu köy hakkında olacak - Bizim hakkımızda da yazdiye yakından gelen boğuk bir ses duyuldu birden. İrkildim."

3) «Время от времени с её губ слетали непечатные идиомы - это случалось в те моменты, когда Людмила в очередной раз сталкивалась с вопиющими, на её взгляд, примерами неряшества. "Ну уж нет, с балконом я не буду разбираться, ну его, пускай Вика", - сказала она и немедленно полезла туда, гремя стеклом и железом, и стала со скрежетом выдирать что-то из горы тлелого хлама и шумно кидать вниз. "Это что же, - выкрикивала она время от времени, заглядывая на секунду в комнату раскрасневшимся лицом. - Это что же!» [Андрей Волос. Недвижимость (2000) // «Новый Мир», 2001]. Krş.: ... с балконом я не хочу разбиратъся...

Çev.: "Ara ara ağzından hoş olmayan ifadeler çıkıyordu, bu, Ludmila, ona göre, iç parçalayıcı bir düzensizlik gibi gelen durumlarla karşılaştı̆̆ zamanlarda olurdu: Ama artık hayır, balkonu düzenlemeyeceğim, Vika uğraşsın - diye söylendi ve cam ve demir sesleriyle yavaşça balkona geçti ve yanan eski eşya yığının içinden gıcırtılı bir sesle bir şey çıkarıp gürültüyle aşağı firlatmaya başladı.”

4) «Многим своим знакомым и подругам она рассказывала, что я во время школьной олимпиады буду играть главную роль по сказкам Пушкина» [Фазиль Искандер. Мученики сцены (1989)] Krş.: ... во время школьной олимпиады хочу, намерена, собираюсъ играть главную роль...

Çev.: “Tanıdıklarının ve kız arkadaşlarının çoğuna, okul Olimpiyatı sırasında Puşkin'in hikayelerine dayanan baş rolü oynayacağın söyledi.”

$\mathrm{Bu}$ ve benzer örneklerde söz konusu eylemlerin geleceğe yönelik bir zaman diliminde gerçekleştirilmek istenmesine yönelik bir niyetin olması söz konusudur. Bu bakımdan analitik gelecek zaman yapıların kiplik anlamları için istek ve niyet anlamlarının bulunduğunu söyleyebiliriz. Belirtilen anlamların yanı sıra ret anlamı da analitik gelecek zamanların kiplik anlamları arasında gösterilebilir. Bu yapıların ret anlamında hayret dolu bir kızgınlık ve öfke anlamlarını aktarmalarının yanında gelecek zaman diliminde aktarılan eylemin gerçekleştirilmeyeceği anlamı ortaya konmaktadır, söz konusu ret anlamı da buradan gelmektedir:

«- Буду я перед всякой (он выругался) извиняться! - грубо сказал мужчина» [А. Слаповский, Жизнь Лагарпова (1999)]

Çev.: “Adam kabaca -Bir de ondan (sövdü) özür mü dileyecĕ̆im!”-dedi.

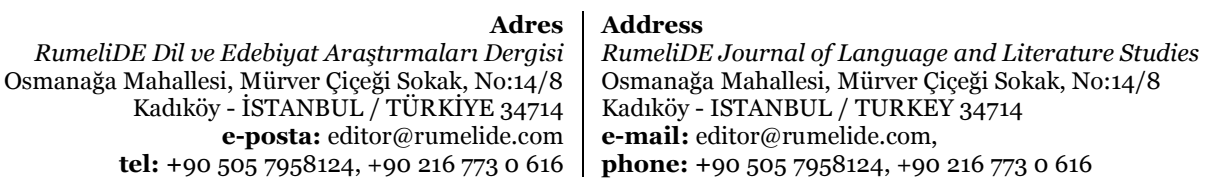


«- Буду я ещё денъги тратить! - первым кричит председатель» [Н. Радулова, Между свечкой и тьмой, «Огонек», 2013] (ret ve kızgınlık, öfke) (Çuykova 2019: 237).

Çev.: "Bir de para mı harcayacă̆ım! diye bağırdı başkan ilk olarak."

Her iki cümleyi de ayrı ayrı ele aldığımızda hepsinde "eylemi gerçekleştirmeyi kızgınlık ve öfke duygusuyla reddetme" anlamlarının ön plana çıktığını görebiliriz. Bir sonraki ifade de ise eylemi gerçekleştirmeye yönelik ret anlamı belirginliğini kaybetse de yine benzer duygularla karşı gelinen olguya yönelik isyan dolu bir inkar durumu söz konusudur:

- Какой умный, - усмехнулся Салтыков и снова стукнул тростью об пол. - Ещё учить меня будет, малец! (kızginlk, öfke, hayret) [В. Дьякова. Фафоровый бес (2019)].

Çev.: "Saltıkov -Aman ne akullı! - diyerek sırtt ve yeniden bastonuyla yere vurdu -Bir de bana öğretecek, çocuk!”

$\mathrm{Bu}$ anlam çerçevesindeki kullanımlar 1) kızgınlık, öfke gibi duygu aktarımı aracılı̆̆ıyla yerine getirilmesi reddedilen eylemler ve 2) kızgınlık, hayret ve öfke başta olmak üzere olumsuz duygu yoğunluğu aktaranlar olmak üzere iki alt gruba ayırılarak da incelenebilir.

\section{Sentetik gelecek zaman yapıları}

Çağdaş Rus dilinde bitmişlik türündeki basit gelecek zaman yapıları, analitik yapıdaki gelecek zaman formlarının bitmemişlik türünün karşıt çifti olarak ele alınırlar. ${ }^{23}$

Basit gelecek zaman yapıları (простые формы будущего времени) olarak da adlandırlan sentetik gelecek zaman yapıları (синтетические формы будущего времени) bitmişlik türü fiil gruplarında görülen ön ek veya iç eke sahip tek yapıda ifade edilen fiil çekimleridir. Bitmişlik türü fiillerde gelecek zamanın görünüş anlamı eylemin gelecekte kesin olarak gerçekleştirilip tamamlanacağı, sınır noktasına ulaşmış olacağıdır. Bu anlam aynı zamanda sentetik gelecek zaman yapılarının birincil ve temel anlamını da oluşturmaktadır. Konuşmacı ve dinleyici için bu yapıda aktarılan gelecek zaman anlamı, muhakkak surette gerçekleşecek olan tek seferlik ve bir bütünü kapsayan yani tamamlanacak olan eylemlere işaret eder. İkincil yani yan anlamında ise 1) şimdiki zamanda ${ }^{24}$ aktarılan genelleşmiş olayları aktarmak için de kullanılabildiği gibi (он никогда плохого не скажет и если что всегда извинится - hiçbir zaman kötü bir şey söylemez, gerekirse her zaman özür diler); 2) geçmişte tekrar etmiş, süreklilik göstermiş, düzenli olarak gerçekleştirilmiş eylemleri aktarmak için de kullanılabilmektedir. Bu anlamın gelecek zaman yapıları ile ifadesinde geçmiş zaman yapılarından farkı, aktarılan olay veya olay örgüsüne canlılık katmasında yatmaktadır. Anlatılan durum sanki konuşan/anlatan kişinin gözleri önünde canlı bir biçimde aktarllyormuş etkisini içerisinde barındırmaktadır:

23. Rus dilinde basit gelecek zaman formlarının zaman kategorisindeki yerine ilişkin daha ayrıntılı teorik yaklaşımlar için bkz. L.Ç. Dalkılıç. Formı prostogo buduşevo vremeni v znaçenii neaktualnogo nastoyaşevo v sovremennom russkom yazıke. Dis. Na soisk. Uç. Stepeni k.f.n., St.Petersburg, 2013.

24 Rus dilinde şimdiki zaman geçmiş ve gelecek zaman arasında bir konumda yer alır, bu bakımdan şimdiki zaman yapıları basit gelecek zaman yapılarına oranla işlevsel ve anlamsal genişliği ile ayrılmakta bu nedenle de gelecek zamanın anlamsal alanlarına yayılabilmektedir (завтра я еду в Моску - yarın Moskova’ya gidiyorum). Gelecek zaman yapılarının şimdiki zamanın anlamsal alanlarına kayması ise, daha nadir olmakla birlikle bağlam bazında spesifik kullanımları gerektirir.

RumeliDE Dil ve Edebiyat Araştırmaları Dergisi Osmanağa Mahallesi, Mürver Ciceği Sokak, No:14/8 Kadıköy - ÍSTANBUL / TÜRKIYE 34714 e-posta: editor@rumelide.com tel: +90 $5057958124,+902167730616$
Address

RumeliDE Journal of Language and Literature Studies

Osmanağa Mahallesi, Mürver Çiçeği Sokak, No:14/8

Kadıköy - ISTANBUL / TURKEY 34714

e-mail: editor@rumelide.com,

phone: +90 505 7958124, +90 2167730616 
«Ранъше жил в Ленинграде, и вот его тогдашняя жена рассказывала, что пошлёт Алика, бывало, вынести ведро с мусором, а он въйдет утром с ведром - $u$, задумавиись о своём, юмористическом, пойдёт гулять по городу.» [И. Э. Кио. Иллюзии без иллюзий (1995-1999)]25.

Çev.: "Eskiden Leningrad'da yaşardı, o zamanki karısı ise, Alik’i (Anatoliyi) çöp atması için gönderir, o da sabah çöp atmak için evden çıkar ve mizahla ilgili kendi düşüncelerine dalarak şehirde gezintiye çıkarda."

$\mathrm{Bu}$ bakımdan, gelecek zaman yapıları geçmişte yaşanmış olayları aktarırken anlatıma canlılık katmanın yanı sıra, ifadelere bir duygu yoğunluğu da yüklemektedir.

Birincil anlamının yanı sıra sentetik gelecek zaman yapıları ile birçok kiplik anlamı aktarılabilmektedir. Kimi çalışmalarda bu yapıların sundukları anlamlar, sadece imkânsızlık ve olasılık anlamları ile değerlendirilse de (Bondarko, 1962: 29) söylem anında söz konusu durum ya da olaya ilişkin belirli bir tutum sergileyen durumların çok daha geniş bir anlam çeşitliliği yansıttığı söylenebilir. Örnek incelemeleri çerçevesinde bu yapıların aktardıkları kiplik ifadelerini şu şekilde suralayabiliriz:

1) imkânsızlık;

2) olasilık;

3) kesinlik, emin olma;

4) zorunluluk (talimat);

5) rica.

İmkânsızlık (невозможность) anlamı olumsuz bir duruma işaret ettiğinden bu yapıdaki anlamlar fiilin olumsuzluk eki ile kullanılması durumunda ortaya çıkar. Olumsuzluk anlamı en çok fiilin birinci tekil şahıs çekiminde kullanıldı̆̆ında belirgin olarak kendini gösterir: не скажу, не вспомню, не решу. Вu ve benzeri ifadeler söylemin yapısal anlamı ile çeliştiği için, basit gelecek zaman yapılarının kiplik anlamlarını aktarabildiğini bilmeyenler için sanki kati olarak yapılmayacak eylemlermiş gibi algılanmaktadır, esasında burada eylemin yerine gerçekleştirilmesinin dış etmenlerden dolayı halihazırda mümkün olmadığı aktarılmaktadır: - Вы не скажете, где находится улица Нахимова? (Nahimov sokağı nerededir, söyleyebilir misiniz?)- Нет, не скажу.... Cevapta aktarılmak istenen "hayır söylemeyeceğim" anlamından ziyade, "hayır, maalesef bilmediğim için "söyleyemeyeceğimdir". Yine aynı şekilde, я не решу эту задачу, она слишком сложная (Ви problemi çözemeyecĕ̆im, oldukça zor) gibi bir ifade söylenmek istenen eylemin yapılmayacağından ziyade yapılamayacağıdır. Bu bakımdan yeterlilik anlamını veren -ebilmek fiili ile eş değerdir: не peuy (çözemeyeceğim) = не могу решить (с̧ӧzетет), невозможно решить (çӧzтет mümkün değil).

Basit gelecek zaman yapılarında olasılık ya da mümkün olma anlamı (возможность) da sık görülen kiplik anlamlarındandır. Bu anlam, gerçekliği genel bir yargı olarak dilde yerleşmiş ifadelerde yer edebildiği gibi любой (herkes) скажет (söyler), покажет (gösterir), поможет (yardım eder) $v b .=$ может сказать, показать, помочь (-ebilir) $v b$. içerisinde yeterlilik anlamını da barındırmaktadır.

25 Kaynak: Rusça Ulusal Derlemi (национальный корпус русского языка).

Adres $\mid$ Address

RumeliDE Dil ve Edebiyat Araşttrmaları Dergisi $\quad$ RumeliDE Journal of Language and Literature Studies

Osmanağa Mahallesi, Mürver Çiçeği Sokak, No:14/8 Osmanağa Mahallesi, Mürver Çiçeği Sokak, No:14/8

Kadıköy - ÍSTANBUL / TÜRKIYE 34714 Kadıköy - ISTANBUL / TURKEY 34714

e-posta: editor@rumelide.com e-mail: editor@rumelide.com,

tel: +90 505 7958124, +90 2167730616 phone: +90 505 7958124, +90 2167730616 
Bununla birlikte eylemin kaçınılmaz bir şekilde gerçekleşme olasılı̆̆ına vurgu da yapılabilmektedir: Иди домой, а то замерзнешъ; Руки тясутся, а я в обморок упаду; Волны хлестали в борт лодки - вот-вот опрокинут (Şelyakin, 2007: 193).

Çev.: (sırasıyla) "Eve git, yoksa donacaksın"; "ellerim titriyor, sanırım bayılacağım"; "dalgalar teknenin güvertesine vuruyordu, şimdi alabora edecek".

Kesinlik (уверенность) anlamı, eylemin söylendiği şekliyle kesin bir şekilde gerçekleştirileceğine ilişkin bir emin olma halini yansitır: Пока он ещё ничего по молодости лет не сделал, но все знали, что в скором времени сделает что-то значительное ${ }^{26}$. [Василий Аксенов. Пора, мой друг, пора (1963)].

Çev.: "Yaşının genç olmasından ötürü henüz hiçbir şey yapmamıştı ama herkes yakında önemli bir şey yapacă̆ım biliyordu."

Bir nevi talimat anlamını yansıtan zorunluluk anlamı (вынуждённость) çerçevesinde sentetik gelecek zaman yapıları ise, dilde emir kiplerinin söylemi yerine getirme ve harekete geçirme anlamları ile benzerlik göstermektedir: Позвонишь ему и расскажеши всю правду; Он у меня заговорит!; Быстренько отнесешъ докуметы и вернёшъся на работу $v b$.

Çev.: "Onu arayacak ve tüm gerçeği anlatacaksın; konuşacak (опи konuşturacağım anlamında); Çabucak belgeleri götürüp işe geri döneceksin.”

Son olarak bu yapıların rica anlamındaki kullanımları konuşma anı ile denk düşen ifadeleri aktarmaktadır: nonpouy не шуметь (gürültü yapmamanızı rica edeceğim). Böyle bir kullanım açısından basit gelecek zaman yapıları, göreceli zaman çerçevesinde geçmişte tekrar etmiş eylemler ile geçmişte aniden meydana gelmiş olan eylemlerin ifadesindeki kullanımları ile benzerlik göstermektedir (Dalkılıç, 2018: 303-306).

\section{Sonuç}

Rus dilinde zaman kategorisi dilde görünüş kategorisi ile bir bütün içerisinde incelendiğinden bu yapıların anlamsal oluşumları da görünüş kategorisinin etkisi altında gerçekleşmektedir. Bu da anlamsal olarak onun sadece "gelecekte vuku bulacak olan eylem" tanımının dışına çlkmasına ve kullanım alanlarının belirli sınırlar dahilinde tezahür etmesine yol açmıştır. Bu Fransız gramer geleneğinde adlandırıldığı şekliyle iç zaman ve dış zaman şeklindeki ayrımı hatırlatmaktadır. Bahse konu herhangi bir olay genel çerçevede dış zamanda yer etmektedir, diğer bir deyişle, konuşma anına göre önce, sonra veya konuşma anı ile eş zamanda yer edebildiği gibi, bahse konu olan durum iç dinamikleriyle zamanla kendine has bir ilişki örgüsüne girebilir. Zaman kategorisi “dış zamanı yansıtırken, iç zaman ise görünüşü” yansıtmaktadır. Zaman her zaman öncelik-eşzamanlık-sonralık ilkesi ile ilerlerken, görünüş bu anlamsal özelliklerin çoğunlukla dışında kalarak iki veya daha fazla durum arasındaki ilişkiyi ortaya koymaktadır. Bir durum bir diğerinin reddi olabileceği gibi görünüş yapısındaki eylem durumun meydana geldiğini ya da gelmediğini ifade ederken, bir durum soyut bir eylemin somut bir hal alması, ya da bir başka eylemin sonucu veya da birbiri ardına gerçekleşen eylemler zinciri olarak da yer edebilir.

26. Örnek национальный корпус русского языка adlı ulusal derlemden seçilmiştir. 
Bitmemişlik türü fiillerin anlamsal özelliği başlangıç anlamını vermesi, diğer bir deyişle zaman diliminde bir anda var olmamak, ancak sonrasında meydana gelmek, bitmişlik türü eylemlerin anlamsal özelliği ise birbirini izleyen her anda süreç içerisinde var olmak (Glovinskaya 1982: 107) olarak kendini göstermektedir. Bu da esasında gelecek zaman yapılarının anlamsal ve işlevsel özelliklerini etkilemektedir. Buna göre, analitik gelecek zaman yapıları ile hem görünüş hem de kiplik anlamları aktarılabilmektedir. Analitik yapılı gelecek zaman formlarının görünüş anlamları arasında 1) eylemin gelecekte vuku bulacağına yani yerine getirilmiş olacağına, gelecek zaman dilimi içerisinde yer edebileceğine vurgu yapılabilir; 2) zaman belirten ifadeler ile kullanıldığında gelecek zamana yönelik eylemin sürecine, süreçsel uzunluğuna vurgu yapılır; 3) gelecekte tekrar etmesi ön görülen ya da tekrar edecek olan eylemler, tekrar eyleminin süresi belirli kılınarak aktarılır; 4) iletişim anında konuşanın dinleyene yönelik olarak gelecek zaman diliminde aktardığı ifadelerin kişiyi konuşma anından alarak bir sonraki eyleme geçmesi için kullanılır.

Analitik yapılı gelecek zaman formlarının kiplik anlamları arasında ise, eylemin yapılacak olmasından ziyade daha çok geleceğe yönelik bir niyet, istek, "beklenti” (Çebışev, 2016: 105) belirtme, söz verme, tahmin yürütme, eylemi yerine getirmeyi reddetme, bir duruma karşı öfke, kızgınlık, hayret yansıtma anlamları ön plana çımaktadır.

Sentetik yapılı gelecek formlarında yine aynı şekilde hem görünüş hem de kiplik anlamlarına rastlanmaktadır. Görünüş anlamları arasında muhakkak surette ve tek seferde olmak üzere eylemin gelecekte kesin olarak gerçekleştirilip tamamlanacă̆ı sınır noktasına ulaşmış olması yer almaktadır. $\mathrm{Bu}$ yaklaşım çerçevesinde eylemlerin sınır noktasına ulaşmış olarak tamamlanmışlık vurgulamaları analitik gelecek zaman yapılarından ayrılmalarındaki ve bir yapının bir diğerinin yerine neden her zaman kullanılamayacağını açılayan en önemli etmendir. Kiplik anlamlarına gelince, tıpkı analitik gelecek zaman formlarında olduğu gibi, çok çeşitli olmakla birlikte ön plana çıkan anlamlar arasında imkânsızlık, olasılık, kesinlik, emin olma, zorunluluk (talimat), rica anlamları sıralanabilir.

$\mathrm{Bu}$ inceleme bize yabancı dil eğitiminde yapısal-tasvirci, başka bir deyişle sadece fiil çekimlerine odaklanılarak aktarılan biçemsel bir betimlemenin ötesine gidilmesi gerektiğini ve bu yapıların ele alınmasında işlevsel-iletişimsel gramer çerçevesinde bir yaklaşımın da göz ardı edilmemesi gerektiğini açıkça göstermektedir. Esasında sadece Rusçadaki gelecek zaman yapıları için değil dildeki diğer zaman dilimlerinin işlevlerinin daha iyi anlaşılabilir olması açısından bu formlarla aktarılan ifadelerin kullanım alan ve amaçlarına göre durum odaklı olarak incelenerek sunulması gereklidir. Bu sadece Rus dilinde birbiri ile bağlantılı olan zaman-görünüş sisteminin daha iyi anlaşılmasını sağlamakla kalmayacak, aynı zamanda Rusça-Türkçe dil çifti bazında yapılacak karşılaştırmalı zaman ve görünüş çalışmalarında diller arası farklılıkların daha belirgin bir biçimde ortaya konmasına da olanak sağlayacaktır.

\section{Kaynakça}

Bondarko, A.V. (1962), "Sistema glagolnıh vremyon v sovremennom russkom yazıke". Voprosı yazıkoznaniya, No 3, 27-37.

Bradley, B.C. (1911), "'Shall and Will. A Historical Study". Transactions and Proceedingd of the American Philological Association Vol. 42, 5-31.

Çebışev, F.A. (2016), "Buduşee vremya glagola i ego svyaz s semantikoy ojidaniya”. Vestnik Vyatskogo gosudarstvennogo universiteta, № 10, 102-106.

Çuykova, O. Yu. (2019), Buduşee vremya v russkom yazıke: semantika, pragmatika i kontekst. Jezyk i metoda, № 6, 233-242.

\footnotetext{
RumeliDE Dil ve Edebiyat Arașttrmaları Dergisi Osmanağa Mahallesi, Mürver Ciçeği Sokak, No:14/8 Kadıköy - ISTANBUL / TÜRKIYE 34714 e-posta: editor@rumelide.com tel: +90 $5057958124,+902167730616$ 
Dalkılıç, L.Ç. (2013), Formı prostogo buduşevo vremeni v znaçenii neaktualnogo nastoyaşevo v sovremennom russkom yazıke. Dissertatsiya na soisk. uçenoy stepeni kand. fil. nauk, St. Petersburg.

Dalkılıç, Leyla Ç. (2018), Rus dilinin grameri. Ankara: Gece kitaplığı.

Dalkılıç, L.Ç. (2018), "Rusça ve Türkçedeki Zarf-Fiil Yapılarındaki Anlamsal Özellikler ve Zaman Kavramı”. DTCF. Cilt 58/2, 1184-1210.

Fries, C. C. (1925), "The Periphrastic Future with Shall and Will in Modern English". PMLA, Vol 40. No Dec. 4., 963-1024.

Glovinskaya M.Ya. (1982). Semantiçeskie tipı vidovıh protivopostavlenii russkogo glagola. Moskva: Nauka.

İzraileviç E.S., Kaçalova K.N. (2003). Praktiçeskaya grammatika angliyskogo yazıka $v$ dvuh tomah. Kiev: Metodika.

Maslov Yu.S. (2004). İzbranne trudı. Aspektologiya. Obşee yazıkoznanie. Moskva: yazıkı slavyanskoy kulturı.

Kolesov V.V. (2010). İstoriçeskaya grammatika russkogo yazıka. St. Petersburg: SPbGU.

Koşevaya İ.G. (2016). Tipologiçeskie sturkturı yazıka. Sfera vido-vremennı znaçeniy. Moskva: Lenand.

Selişev A.M. (1952). Staroslavyanskiy yazık. ç.II. Moskva: Uçpedgiz.

Şelyakin M.A. (2008). Kategoriya aspektualnosti russkogo glagola. Moskova: izd. LKİ.

Skvortsova G.L. (2005). Upotreblenie vidov glagola v russkom yazıke. Russkiy glagol. Moskva: Russkiy yazı. Kursı.

Teoriya funktsionalnoy grammatiki: aspektualnost, vremennaya lokalizovannost, taksis. (2007). Moskva: Komkniga. 